\title{
EVALUATION NUTRITIENTS OF RICE BRAN SECOND QUALITY FERMENTED USING RUMEN FLUID
}

\section{EVALUASI NUTRISI DEDAK PADI KUALITAS KEDUA YANG DIFERMENTASI MENGGUNAKAN CAIRAN RUMEN}

\author{
Ayu Afria Ulita Ermalia*, Osfar Sjofjan and Irfan Hadji Djunaidi \\ Animal Husbandry Faculty, University of Brawijaya, Malang, 65145
}

Submitted: 8 January 2016, Accepted: 18 May 2016

\begin{abstract}
Rice bran is agriculture waste that easy to find. Means to increase biological value of rice bran can do with decrease of highly crude fiber. Treatment that to do with fermentation use rumen fluid from cows. Rumen fluid potential is easy to find in slaughterhouse, this rumen fluid much to never utilization. This purpose of the research for evaluation of rice bran nutrition value that fermentating used rumen fluid, with different levels and long time incubations for get lower crude fiber and higher crude protein content. Methods of this research used Laboratory experiments with Factorial-Random Complete Design $4 \times 4$ and 6 repetitions. First factor is rumen fluid levels (0,30,40,50\%/w) and second factor is long incubations $(0$, $24,48,72$ hours). This result of ANOVA analysis to show that increment rumen fluid levels and long incubations on rice bran fermentating process can decrease dry matter, organic matter, crude fiber, NDF, ADF and NDR content; as well as increase Crude Protein content but not increase crude fat content. The best interaction between rumen fluid levels and long time incubations is $30 \% / \mathrm{w}$ with 72 hours long time incubations, with $10.28 \pm 0.11 \%$ of Crude Protein, $6.46 \pm 0.07$ of crude fat and $22.31 \pm 0.24$ of crude fiber content.
\end{abstract}

(Key words: Fermentation, Rice bran, Rumen fluid)

\section{INTISARI}

Dedak padi merupakan limbah pertanian yang mudah sekali dijumpai. Upaya meningkatkan nilai biologis dedak padi dapat dilakukan dengan menurunkan tingginya kandungan serat kasar. Perlakuan yang dilakukan dengan fermentasi menggunakan cairan rumen ternak sapi. Potensi cairan rumen sendiri mudah didapatkan di Rumah Potong Hewan, cairan rumen ini kebanyakan tidak dimanfaatkan keberadaannya. Tujuan penelitian ini untuk mengevaluasi nilai nutrisi dedak padi yang difermentasi menggunakan cairan rumen, dengan level cairan rumen dan lama inkubasi yang berbeda untuk mendapatkan kadar serat kasar yang paling rendah dengan kandungan protein pakan yang paling tinggi. Metode penelitian menggunakan percobaan Laboratorium dengan RAL pola faktorial 4x4 dan 6 ulangan. Faktor pertama adalah level cairan rumen $(0,30,40,50 \%)$ dan faktor kedua adalah lama penyimpanan $(0,24,48,72 \mathrm{jam})$. Hasil analisis ragam (ANOVA) menunjukkan bahwa penambahan level cairan rumen dan lama inkubasi dalam proses fermentasi dedak padi menurunkan kadar BK, BO, SK, NDF, ADF dan NDR; serta meningkatkan kadar PK; tetapi tidak meningkatkan kadar LK. Interaksi antara level cairan rumen dan lama inkubasi terbaik pada level 30 \% dengan lama inkubasi 72 jam, dengan kandungan zat

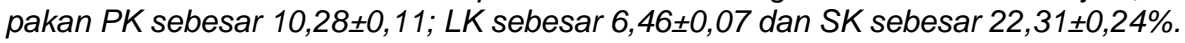

(Kata kunci: Cairan rumen, Dedak padi, Fermentasi)

\section{Introduction}

Based on data from the Dirjen Peternakan and Kesehatan Hewan (2012) the population of broilers in Indonesia in 2010 reached 989.872 million heads; in 2011 as many as 1.177991 billion heads and data while in 2012 as many as 1.266903 billion heads. This business is growing rapidly because the maintenance period relatively short compared than other poultry breeding business, in addition the animal protein also increasing awareness about the importance

*Korespondensi (corresponding author):

Telp. +62 81615742234

E-mail: ue_ayra@yahoo.com 
of consumption consumers meat protein and supply broiler also increasing to balance the market. In a row the growing broiler farms, then the feed is also ever increasing needs. Feed with better quality will be reflected in livestock production is good anyway. Feed provided must be able to meet the needs of livestock, good for live trees, growth or reproduction. The selection of raw materials, processing to storage requires special attention to maintaining the quality of the feed.

This handling aimed to improving the quality of feed, so it can be used full by the animals. Generally, feed that given to broilers is commercial feed, rarely the farmers use feed with his own formulation. It was because feed quality in favorable for the growth of broilers are not as good as commercial feed. Various reasons that caused of the differences quality of them there are the availability of raw materials in the market, the quality of raw materials, handling improper and biological value of feed is less well. Feed materials available continuously and used on each formulation poultry feed one of them is rice bran.

Rice bran is waste in agriculture, it was easily to found it. Rice bran is the waste of the rice mill, rice bran is an energy resources with $<18 \%$ crude fiber (Putrawan and Soerawidjaja, 2007). The availability of rice bran in Indonesia according to Badan Pusat Statistik (BPS) that rice production at 2009 reached 63 million tons that potentially produce rice bran as many as 5 million tons. Efforts to increase biological value of rice bran can be done with decreasing the high crude fiber content. Levels decented of crude fiber in poultry feed required, because the crude fiber in high amounts can disrupt digestibility of feed.

The treatment performed with fermentation using rumen fluid of cattle, this is done with a consideration that the nutrients content of rice bran sufficiently qualified to be better substrates for microbes of rumen. The potential of rumens fluid easily obtained in Slaughterhouse of Animals, rumen fluid is mostly not utilized, whereas with a little considering the presence of microbes in rumen is alleged there is still a possibility this rumen fluid can be use full especially in the field of animals feed that is decreasing the levels of crude fibers for animal feed to poultry. The assessment of fermentation rice bran in decreasing crude fiber content by using rumen fluid and implication to digestibility of feed in poultry are rarely, so that required research to assess this. The purpose of this research were to investigate nutrients value of fermented rice bran using rumen fluid, with different levels of rumen fluid and longtime incubation to get lower crude fiber content and higher protein content on feed.

\section{Materials and Methods}

\section{Location and research time}

Research locations in in Animal Nutrition Laboratory Animal Husbandry Faculty and Microbiology Laboratory University of Brawijaya Malang on March 2014.

\section{Materials}

Rumen fluid was get from cows with traditional rearing as starter that used originates from rumen cattle obtained from Slaughterhouse Malang regions. Rice bran as substrate that used are rice bran the second quality of (SNI, 1996) that obtained from Malang regions.

Preparation fermentation process: equipments: tray, bucket, mixer, beaker glass, filter, jerrycan, scales, thermometer, gloves, plastics, and labels. Materials: rumen fluid and rice bran. The procedure of making starter: rumen fluid let in to the bucket, pour the rumen fluid a little bit while oppressed and filter it into a bucket, filtered rumen fluid put into jerrycan and closed tightly, filtered rumen fluid used as a starter fermented of rice bran. Preparing rice bran as a substrate: weigh rice bran that will be used, oven it in themperature $60^{\circ} \mathrm{C}$ as long as 24 hours, weigh it again ovened of rice bran, caunt difereces of rice bran before ovened and rice bran after ovened, rice bran ready to use for fermentation test sample.

The procedure of making rice bran fermentation (Methods modification of Pasaribu et al., 1998): rice bran with weight known is strerilization used autoklaf with pressure $2 \mathrm{~atm}$ in temperature $121^{\circ} \mathrm{C}$ as long as 15 minutes, after that, the rice bran must be refrigerant, furthermore added rumen fluid as starter with dose a given (\%/w), rice bran batter mixed with rumen fluid to incubation as long as 0, 24, 48 and 72 hours in anaerob condition, after incubation time is finishing, rice bran fermentation is to drying in oven $60^{\circ} \mathrm{C}$, rice bran fermentation was dry. It will 
grinding for get small particle, use for proximate analysis sample to get the best result.

\section{Methods}

Research methodology that used at first stage is Laboratory Experiments using Completely Randomized Design Factorials Pattern $4 \times 4$ and 6 replication. The first factors is level of rumen fluid contents $(0,30$, $40,50 \% / \mathrm{w}$ ) with dry matter value of rice bran before incubation is $92,13 \%$; and the second factor is long time incubation $(0,24,48,72$ hours), so that obtained experiments sample as 96 sample.

\section{Variables}

The variables of this research include proximate analysis which includes dry matter anlisys, anorganic material (ashes), crude fiber, crude protein, and ether extract of fermented rice bran. Crude using method of analysis Van Soest which includes NDF, ADF and NDR, and total population of microbes in rumen fluid using TPC (total plate count) used NA (Nutrient Agar). The measurement of the variables are:

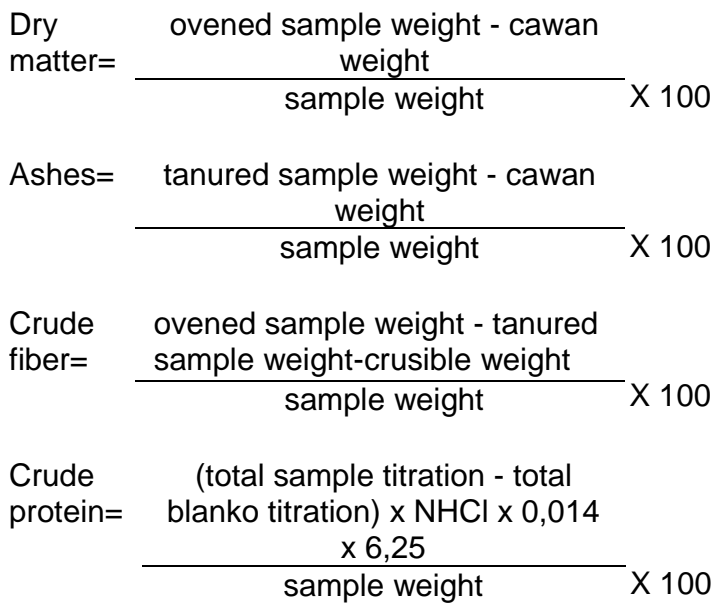

$$
\begin{aligned}
& \text { Ether (flask weight and extracted fat) - } \\
& \text { extract }=\frac{\text { empty flask weight }}{\text { sample weight }} \times 100
\end{aligned}
$$

$$
\begin{aligned}
& \text { Dry ovened sample weight - cawan } \\
& \text { matter }=\frac{\text { weight }}{\text { sample weight }} \times 100
\end{aligned}
$$

NDF $=$ (cawan weight + residue - cawan weight) sample weight $\times 100$
$\mathrm{ADF}=\frac{(\text { cawan weight }+ \text { residue }- \text { cawan }}{\text { weight })} \times 100$

Neutral Detergent Residu (NDR) counted based on comparasion of ADF that ashed and ovened ADF weight multiplied 100.

\section{Data analysis}

The data tabulated using Microsoft Excel program, then the data analized using analysis of variant (ANOVA) with Completely Radomized Design Factorial Pattern $4 \times 4$ and 6 replication (Suhemi, 2011). If there is significant difference continuedly using Multiple Duncan Range Test (Steel and Torrie, 1993). Matematics model from analysis of variant with Completely Radomized Design factorial by Suhemi (2011) is:

$$
Y_{i j k}=\mu+\alpha_{i}+\beta_{i}+(\alpha \beta)_{i j}+\varepsilon_{i j k}
$$

Were: $Y_{i j k}=$ result of observation for $A$ factor level 2, B factor level-j and replication of $\mathrm{k}$

$\mu \quad=$ Median

ai $=$ Effect $A$ factor level-i

$\beta_{\mathrm{j}} \quad=$ Effect $B$ factor level-j

$(\alpha \beta)_{i j}=A B$ interactionin level $A-i, B$ level in $\mathrm{j}$

$\varepsilon_{\mathrm{ijk}}=$ Error in try for $\mathrm{A}$ factor level 2, B factor level-j and replication of $k$ $=$ treatment factor $\mathrm{A}$ $=$ treatment factor $\mathrm{B}$

\section{Results and Discussion}

The results of TPC analisys against the type of facultative anaerobic microbes dominant 1 on rumen fluid

The role of microbes is very important to digest fiber on feed. Microbes rumen could be found attached to the wall of rumen, joined to the particles of feed in rumen and free in rumen fluid. Microbes composition relies heavily to the kind of feed consumed by cattle, if kinds of feed contain many crude fiber total of bacteria would more than protozoa because bacteria needed to digest carbohydrate and protein if feed much containing glucose, total of protozoa will more than bacteria (Gunawan and Purnama, 2001). 
Rumens fluid was collected on UNITRI Slaughterhouse in Malang from Simental cattle on February 2014. The result of anaerob facultative bacteria identification dominant 1 from planting in NA media is Bacillus megaterium with total microbs $1,5 \mathrm{x}$ $10^{6} \mathrm{CFU} / \mathrm{ml}$, ascertainable that Bacillus megaterium given positif respons for kind of BGP and spora test, else positive to fermented glucose, xylose, mannitol, sucrose, maltose and arabinose. The result to show that kind of this bacteria capable to growth between $25-45^{\circ} \mathrm{C}$ pressure. This bacteria form positive with produced spora $>0,9 \mu \mathrm{m}$ diameter, non-pathogen, have aerob obligation with size $2 \times 4-5 \mu$ (stick type).

This bacteria produced vitamine B12 and penicillin, also to produced enzyme that function for steroid synthetic. Penicillin form is natural antibiotic that function to pressing growth pathogen bacteria. Bacillus megaterium what is known as probiotic bacteria can neutralize ammoniac for repair water quality (Irianto, 2003), else it has been use to studying of structure, protein localization and membrane of bacteria (Vary et al., 2007). Growth pattern of Bacillus megaterium in log phase occur in third weeks and finished at fifth weeks. That known in log phase of total bacteria achieve $4,5 \times 10^{11}$ $\mathrm{CFU} / \mathrm{ml}$. Stationer phase occur in fourth weeks to seventh weeks, whereas in eighth weeks to twelveth weeks form dead phase. Optimum $\mathrm{pH}$ revolution of Bacillus megaterium that is 5,5-8 (Belma et al., 2002).

Mackie et al. (1999) explain that microbes species in rumen consist of 200 species approximately $10^{10} \mathrm{cell} / \mathrm{g}$ rumen contents; 25 genus of protozoa approximately $10^{6} \mathrm{sel} / \mathrm{g} \quad \mathrm{cell} / \mathrm{g}$ rumen contents; 5 genus of fungi $10^{6} \mathrm{sel} / \mathrm{g}$ cell/g rumen contents. It was caused anaerobic microbes work optimally in anaerobic condition with temperature of rumen $39{ }^{\circ} \mathrm{C}$ and $\mathrm{pH}$ rumen 6-7 (Sutardi, 1977). The used of rumen contents from Slaughterhouse eject rumen content and filter it bringing decrease the temperature and create the aerobic conditions. The aerobic condition will kill anaerobic microbes, while anaerobic microbes be able to still alive in this condition called facultative anaerobic microbes. Facultative anaerobic microbes that used as a stater, and expected to fix the value nutrients of rice bran.

Isolated Bacillus megaterium species from rumens fluid find out yet. The kind of those microorganism usually founded on soil substrate, rice straw, corn leaves (Madjid, 2009). Microorganism in rumen cows, species and total influence with feed that consumption (Ogimoto dan Imai, 1981).

\section{The effect of level addition rumen fluid on nutrients content of rice bran \\ Fermentation not spontaneously is} fermentation that doing using addition culture of organisms with the selected media that the fermentation process can go faster (Rahayu et al., 1992). Fermentation using solid media is a fermentation that the substrate insoluble in water, but fairly containing water that needed for microbes (Harjo et al., 1989). The result of fermentation gaves as microbes metabolism on a feed ingredient on aerobic condition. The microbes that doing fermentation need energy usualy obtained from glucose, in aerobic condition. The microbes change glucose to water, $\mathrm{CO}_{2}$ and energy (ATP) (Muchtadi and Ayustaningwarno, 2010). According Harjo et al. (1989), profit fermentation solid media is used natural substrate which are single, preparing simple inoculum, able to produce products with higher thickness, loweron control contamination. The incubation condition nearly resembling the natural condition, do not needed temperature control and $\mathrm{pH}$ scrupulous and aeration can be functioned more optimally.

The used of rumen fluid as a starter in fermentation process on nutrient content of rice bran was presented (Table 1). The result detected that occured decreasing dry matter content using rumen fluid as a starter on rice bran fermentation. Dry matter value after incubation has decreased in addition of 0,40 , 30 and $50 \% / \mathrm{w}$ there is continuedly $92,09 \pm 1.43 ; 91.54 \pm 1.17 ; 91.24 \pm 1.30 ;$ and $91.03 \pm 1.48 \%$ (Table 1 ).

These decreasing of dry matter happened because there is microbes activity on ashes used in rice bran, while on addition rumen fluid using more volume rice bran inclined decreasing dry matter content higher too.

Organic matter value has decreased in addition of $0,40,50$ and $30 \% / \mathrm{w}$ there is continuedly $\quad 84.98 \pm 1.14 ; \quad 83.50 \pm 1.08$; $82.41 \pm 1.23$; and $81.49 \pm 1.27 \%$. That is happened because there is microbes activity on used ash. Addition of rumens fluid 30 decrease ash more than $50 \% / \mathrm{w}$, assumted because microbes on rumen fluid on volume 
$30 \% / w$ more optimal than using microbes that containing from the others volume. It will more faster microbes activity on fermentation because there is competited between microbes.

Crude protein content has increased in addition of $0,50,40$ and $30 \% / \mathrm{w}$ there is continuedly $7.25 \pm 0.56 ; 7.33 \pm 1.30 ; 7.34 \pm 0.38$; and $8.09 \pm 0.37 \%$. Higher increasing crude protein content showed in addition rumen fluid $30 \% / \mathrm{w}$. Assumted that factor condition of microbes in there more optimal than using the others volume. Protein on rice bran had complex essential amino acid until had high nutrient value (Ciptadi and Nasution, 1979). High value of protein, it used optimally by microbes. Then, expend of microbes population faster too. More high population of microbes that used protein in feed, for this condition will decrease protein content on these feed. But, protein content in feed will be increase again by as many as microbes that lysis. Because available of protein in feed that used by microbes in a litle value. Microbes compound is protein and then the microbes was lysis and increase protein content on feed. Those condition assumpted agent of protein content increase by the treatment feed fermentation.

Crude fat content has decreased in addition of $40 \% / w$ that $6.42 \pm 0,11 \%$ and increased in addition of 50 and $30 \% / \mathrm{w}$ that $6.53 \pm 0.34$ and $6.62 \pm 0.32 \%$, whereas in addition rumen fluid $0 \% / \mathrm{w}$ was $6.45 \pm 0.25 \%$. Rice bran that used have a crude fat content $7.10 \%$. Microbes activity on volume of rumen fluid 30\%/w more quickly and more optimally in rice bran fermentation caused anaerobic facultative microbes assumpted just work to cut bonds of crude fiber, and then fat that bounded with crude fibers component more many regardless. Rice bran from the start had more oil content and more increasely that implicated by fat addition that regardless, until induce increasing crude fat content of rice bran.

Rice bran had too unsaturated fat, this fat more savely on cholesterol. Excepted that, tocoferol and tocotrienol content functioned as a anti occidant (Auliana, 2011). Fat content on rice bran more higher. Rice bran oil obtained unsaturated acid up to $80 \%$ (Ciptadi and Nasution, 1979). Crude fiber content has decreased in addition of 0,40 , 50 and $30 \% / \mathrm{w}$ continuedly $27.78 \pm 0.68$;
$26.72 \pm 0.72 ; 25.98 \pm 1.44$; and $23.11 \pm 0.45 \%$. Decreasing of crude fibers gave significantly influenced on addition rumen fluid using $30 \% / \mathrm{w}$, it happened because anaerobic facultative microbes that obtained on rumen fluid produce enzyme that used to rend crude fiber bonds of rice bran, more microbes value still alive on rumen fluid, more quickly fission process crude fiber bonds. Crude fibers after rended used by microbes for metabolism process as energy resources. The product of those metabolism showed with addition total population of microbes that efflorescent and increasing total produce of enzyme, while microbes that lysis all of body component become microbes protein and will be increase protein content on feed. Crude fibers that apparted by microbes will unbend fat acid that bounded with component then increase crude fat content on feed.

The low of protein content, digestibility, amino acid, and more high crude fibers on agriculture waste (Hutagalung, 1978; Yeong, 1982; Zamora et al., 1989) usually become deveider factor on used as poultry feed, to repair nutrient value on those agriculture waste need a process that can take all aspect were physics, chemistrys, and biologys, that used fermentation technology (Pasaribu et al., 1998).

The result of Van Soest analysis parting fraction become Neutral Detergent insoluble Fiber (NDF), Acid Detergent insoluble Fiber (ADF), hemicellulose, sellulose, lignin, and silica. Crude fibers obtained sellulose, hemisellulose, and lignin. Sellulose and hemisellulose are component on plants cell walls and can not digested by non-rumminantia. Lignin is not a group of carbohydrate, but in range of plants and a part of carbohydrate. Lignin as a lining protection be one with sellulose and hemisellulose on plants structure tissue when growth can protect them from bacteria. Lignin always associated with sellulose and hemisellulose then from aspect nutrition need more attention as important part on crude protein. Lignin is a combination from some compound that so tight about the bonds between one compound with the others compound. Lignin is very strong in every chemistry degradation, so do enzymatics degradation (Jola and Jet, 2014).

Neutral Detergent insoluble Fiber is a method that quickly to know total fibers on 
cell walls containeing on plants fiber, while ADF used as a part of preparation for lignin determenation, then hemisellulose can be estimated from cell walls structure differences with those ADF (Harris, 1970). ADF can be used to estimate dry matter digestibility and poultry feed energy (Ensminger and Olentine, 1980), estimate of dry matter forages consumtion. More high NDF and ADF the quality of forages more low. Increasing ADF content a forage will be causes increasing NDF on those forages (Chuzaemi, 1994).

Analysis result in Table 1 knowed that NDF content has decreased in addition of 0 , 30,40 and 50\%/w continuedly $45.12 \pm 0.95$; $44.15 \pm 1.78$; $43.40 \pm 1.30$; and $42.50 \pm 0.65 \%$. Decreasing of ADF content in addition of 0 , 40,50 and $30 \% / \mathrm{w}$ continuedly $36.42 \pm 0.97$; $35.19 \pm 0.71$; 35.15 \pm 1.88 ; and $33.96 \pm 0.61 \%$. Decreasing of NDR content in addition of 0 , 30,40 and $50 \% / w$ continuedly $24.37 \pm 0.81$; $22.94 \pm 1.02 ; 2.37 \pm 0.94$; and $22.19 \pm 0.42 \%$. It showed that enzyme was produced by anaerobic facultative microbes like as amylase and xylanase has worked optimally to sugar fermenting. So when NDF content has decreased, ADF content will decrease too. NDR content has decrease because the ADF content decreased. NDR is a residual of ADF and contains sellulose and sillica.

According Kompiang et al. (1992) if NDF content has decreased after feed treatment that showed there was a sellulose cell walls broke, so feed was easy to digest. Added by Akmal (1994) that NDF and ADF content has decreased cause among fermentation process happened, there was broke a lignohemisellulose and lignosellulose bonds. Although, bonds break caused by $\mathrm{pH}$, developing microbes, and anaerobic stability. The higher NDF content decrease the dry matter consumption (Tjardes et al., 2002).

\section{The effect of duration incubation on nutritional value of rice bran}

Culture condition to produce enzyme must has an attention. Some factors are $\mathrm{pH}$ for growth medium, incubation time, inoculan size, nitrogen and carbon sources (Murad and Azzaz, 2010). Long time incubation on treatment are $0,24,48$, and 72 hours showed (Table 2).

Longtime incubation in 0 hour, there was decreasing value of crude protein, crude fat, and crude fiber. The fermentation process still continue although there is no long time incubation. Probability, there is an enzyme activity, not activity of microbes. Long time incubation in 24 hours did not gave a differences nutrition value than 0 hour. If see on NDF content, long time incubation at 24 hours more litle than 0 hour. Assumpted cause microbes activity on incubation time 24 hours still did not optimally. Ash that obtained on rice bran assumpted just used for coppied total bacteria, until fermentation activity that happened still limited. Longtime incubation 48 hours can decrease crude protein content up to $6.97 \pm 0.13 \%$, with content of crude fat, crude fiber, and NDF that not significant influenced by long time incubation 0 hour and 24 hours. Crude protein has decrease probably caused crude protein content in rice bran used by microbes for metabolism activity, while synthese enzyme activity for fermentation not optimally yet. Long time incubation 78 hours showed that microbes activity in fermention process of rice bran more optimally than the others long time incubation. It was happening on increasing crude protein content until $8.45 \pm 1.08$; with crude fat content not significant influenced, but there is still decrease cride fiber content up to $8.45 \pm 1.08$, so do in NDF value up to 42.97 \pm 1.01 . It was assumpted cause microbes activity on enzyme synthese more optimal with total microbes, so component degradation of fiber happening more quickly and maximal.

Long time incubation gave significantly influenced on microbes product formation (Murad and Foda, 1992; Murad, 1998; Murad and Salem, 2001). There are developing differences of Bacillus megaterium bacteria on various planting media concentration bacteria showed that media composition most important on Bacillus megaterium development. Little differences on nutritional that suplyed probably happened to changes implicated limited nutritional and influenced on regeneration cells of microorganism (Hudayanti, 2005 cit. Khurorin, 2006).

\section{Interaction beetwen level rumen fluid and longtime incubation on nutritional value of rice bran}

Interaction between level rumen fluid and longtime incubation showed there is presence connection and or effect between level rumen fluid factor with incubation factor (Table 3). 
Concerning microbe activities in fermenting process of rice bran. Interaction between level rumen fluid with long time incubation based on the Table 3 showed that DM value experience decrease $89.97 \pm 1.17 \%$ on incubation level $50 \% / w$ with long time incubation 0 hour. DM value highest at $93.74 \pm 0.32 \%$ that is in $0 \% / w$ level rumen fluid with long incubation 0 hour. This matter showed that more increase on level adding rumen fluid so increase too microbe mass that used organic matter from DM. Microbe that increase cause increasing organic matter digestibility with sign more decrease organic matter of rice bran. Microbe mass assessment increasing with long time incubation more than 0 hour gives effect concerning to level process and product fermentation.

Crude protein contents lower on $0 \% / \mathrm{w}$; 48 hours interaction that $6.48 \pm 0.07 \%$ and higher on adding 30\%/w rumen fluid with long time incubation 72 hours that $10.28 \pm 0.11 \%$. This condition showed that microbe mass in that level mentioned concerning in match condition and optimum, balancing with condition of rice bran that enough for life and microbe metabolism process, so with long time incubation that more long cause that microbe will be optimum in fermentation process.

Crude fat contents lower on adding $40 \% / w ; 24$ hours that $5.94 \pm 0.09 \%$ and higher on $30 \% / \mathrm{w} ; 0$ hour that $6.99 \pm 0.02 \%$. Concerning in adding $40 \% / w ; 24$ hours, all organic matter in rice bran used with rumen microbe, so decrease crude fat at first, kind from rice bran substrat or solute in rumen fluid as product microbe activity before used starter.

Crude fiber contents lower on adding $30 \% / w ; 24$ hours that $21.99 \pm 0.29 \%$, and higher $0 \% / w$; 0 hour that $28.27 \pm 0,01 \%$. The balancing microbe exactly and availability nutrient of substrat concerning gives optimum condition so fermentation process go appropriate that desire. Bacillus megaterium be familiar capable to degradation crude fiber in feed and produce amylase enzim.

NDF contents lower on adding 40\%/w; 72 hours that $41.36 \pm 0.46 \%$, and higher on $30 \% / w ; 0$ hour that $46.08 \pm 0.15 \%$. ADF contents decreasing seen up and down but tend decreasing on adding with different levet and same in long time incubation. ADF contents lower on adding 30\%/w; 72 hours that $31.29 \pm 0.33 \%$, and higher on $0 \% / w ; 48$ hours that $37.09 \pm 0.43 \%$. NDR contents lower on adding $40 \% / \mathrm{w} ; 24$ hours that $20.90 \pm 0.31 \%$, and higher on $0 \% / w ; 24$ hours that $24.92 \pm 0.27 \%$.

Up and down condition that showed from result interaction between level rumen fluid and longtime incubation showed that in fermentation process in last, microbe activity concerning un-optimum, total microbe mass, $\mathrm{pH}$ and availability of organic matter concerning because up and down fermentation process of rice bran. Oxygen in substrat can be effect on process and result. Respiration process of substrat in last as long as oxygen availability. Respiration will to increase losing DM, disturbing ensilage process, decreasing nutrition value and stability product. Generally of water contents optimum for fermentation process that $65 \%$ (Coblenzt, 2003 cit. Murni et al., 2008). Level of this content can be easy for fermentation process and commonly help to disappear of oxygen as long as boxed process. Water content more than $70 \%$ cause result of fermentation less acid and have higher Butyrate and $\mathrm{N}$ ammonia. Water content less from $50 \%$ cause on limit fermentation so product fermentation less stability with lower Lactat concentration and higher $\mathrm{pH}$ and difficult to loss oxygen on entering and substrat boxed (Murni et al., 2008).

\section{Conclusion}

Adding level rumen fluid and long time incubation in fermentation process of rice bran decrease organic matter, crude fiber, NDF, ADF and NDR content; and increase crude protein content, but not increase crude fat content. Best interaction between level rumen fluid and long time incubation that $30 \% / w ; 72$ hours with nutrition value crude protein that $10.28 \pm 0.11$; crude fat that $6.46 \pm 0.07$ and crude fiber that $22.31 \pm 0.24 \%$.

\section{References}

Akmal. 1994. Pemanfaatan wastelage jerami padi sebagai bahan pakan sapi $\mathrm{FH}$ jantan. Tesis. Fakultas Pascasarjana IPB, Bogor. 

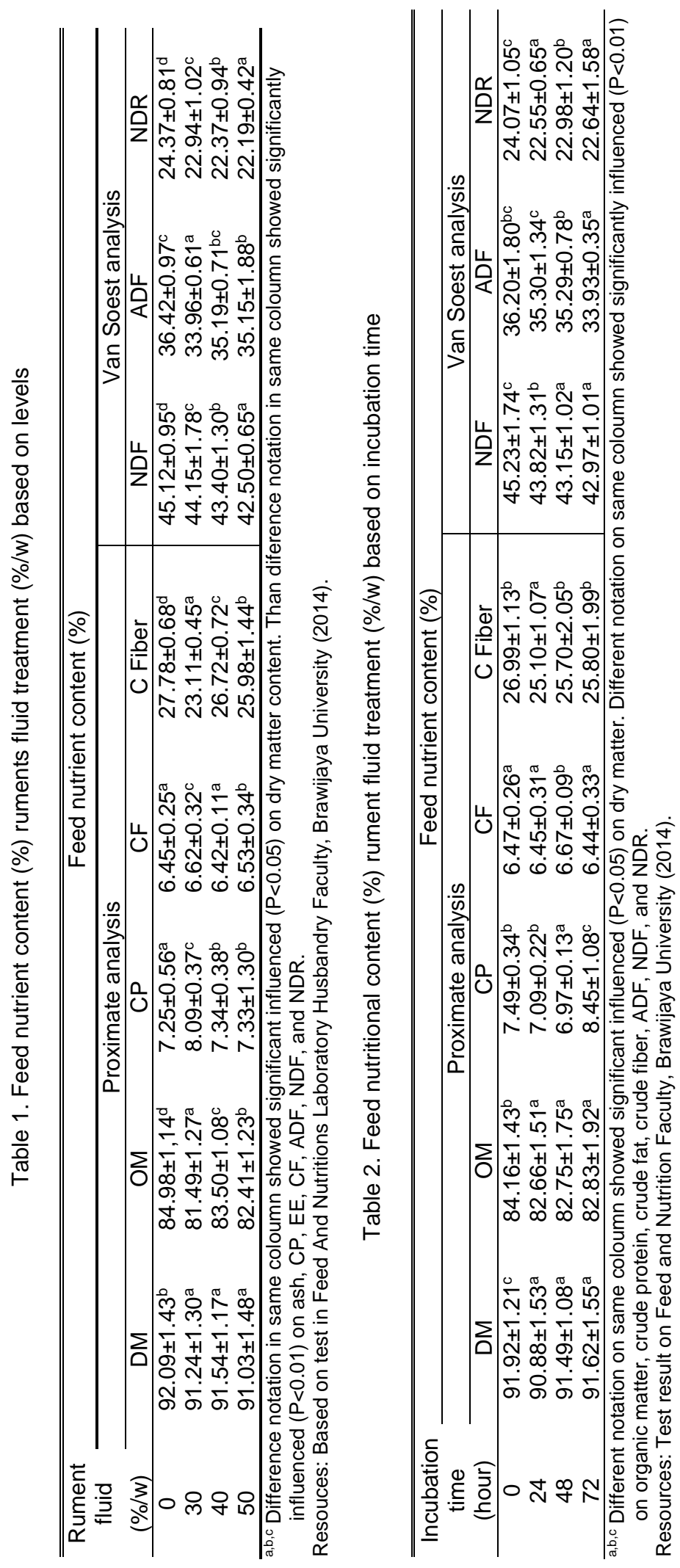


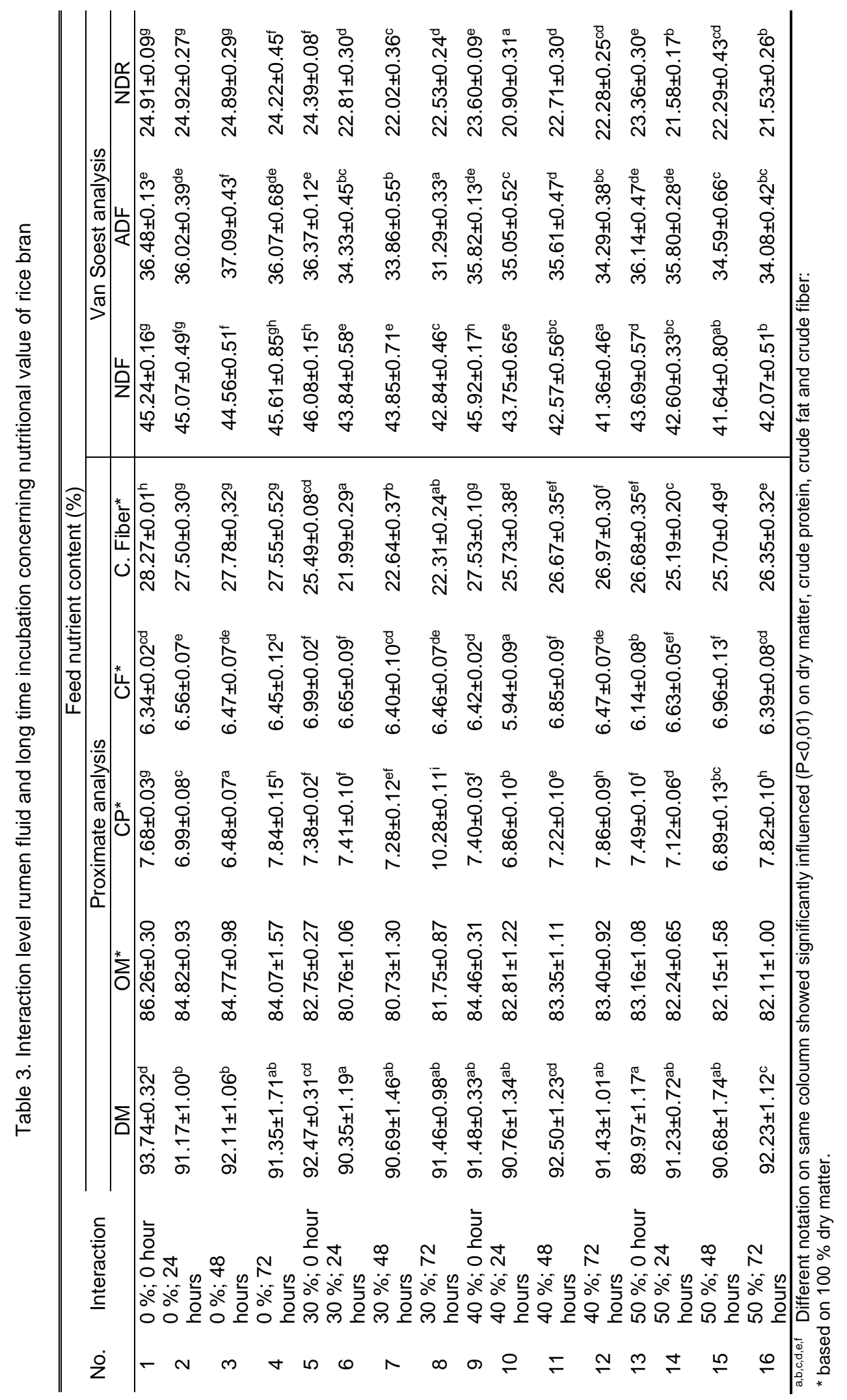


Auliana, R. 2011. Manfaat bekatul dan kandungan gizinya. April 2011 dalam kegiatan dharma wanita, FT UNY.

Belma, A., N. Zehra and B. Yavuz. 2002. Determination of PHB growth quantities of certain Bacillus species isolated from soil. Turkish Electronic J. Biotechnol. Special Issue: 24-30.

Chuzaemi, S. 1994. Pengaruh urea amoniasi terhadap komposisi kimia dan nilai gizi jerami padi untuk sapi potong. Thesis Pasca Sarjana UGM, Yogyakarta.

Ciptadi, W. dan Z. Nasution. 1979. Dedak padi dan manfaatnya. Departemen Tehnologi Hasil Pertanian, Fakultas Tehnologi Pertanian. Institute pertanian Bogor, Bogor.

Dirjen Peternakan dan Kesehatan Hewan. 2012. Pedoman umum pengembangan lumbung pakan unggas.

http://www.deptan.go.id/pedum2012/p eternakan/4.3.\%20 pedum\%20lp $\% 20$ unggas.pdf. Diakses pada 30 September 2013.

Ensminger, M. E and C. G. Olentine. 1980. Feeds and nutrition. The Ensminger Publishing Company, USA.

Gunawan dan R. D. Purnama. 2001. Teknik pengambilan cairan rumen pada domba. Temu Teknis Fungsional Non Peneliti 2001.

Harjo, S., S. Indrasti dan T. Bantacut. 1989. Biokonservasi pemanfaatan limbah industry pertanian. Pusat Antar Universitas, Pangan dan Gizi, Institut Pertanian Bogor, Bogor.

Harris. L. E. 1970. Nutritional research techniques for domestik and wild animal. Anim. Sci. Dept. Vol 2. Utah State University, USA.

Hutagalung, R. I. 1978. Non traditional feedingstuffs for livestock. In: Feedingstuffs for Livestock in Southeast Asia. Devendra, C. and R. I. Hutagalung (eds). Malaysian Society of Animal Production. Serdang, Malaysia. pp. 259-288.

Irianto, A. 2003. Probiotik untuk akuakultur. Universitas Gajah Mada, Yogyakarta.

Londok, J. J. M. R. dan J. S. Mandey. 2014. Potensi fitokimia dan aktivitas antimikroba daun sirsak (Annona Muricata Linn.) sebagai kandidat bahan pakan ayam pedaging. Jurnal LPPM Bidang Sains dan Teknologi Vol. 1 No. 1 Oktober 2014.
Khurorin, A. 2006. Optimasi pertumbuhan bakteri probiotik Streptococcus lactis dengan kombinasi konsentrasi molase dan ammonium sulfat. Skripsi Biologi. Fakultas Sains dan Teknologi. Universitas Airlangga.

Kompiang, I. P., B. Tangendjaja, dan $\mathrm{H}$. Iqbal. 1992. Pembuatan silase isi rumen. Prosiding Agroindustri Peternakan di Pedesaan. BPT Puslitbangnak, Bogor.

Mackie, R. I., R. I. Aminov, H. R. Gaskins and B. A. White. 1999. Molecular microbial ecology in gut ecosystems. Proceeding of The $8^{\text {th }}$ International Symposium on Microbiology Ecology, Atlantic Canada Society for Microbiology Ecology. Halifax, Canada.

Madjid, A. 2009. Dasar-dasar ilmu tanah.bahan ajar online. Fakultas Pertanian Unsri \& Program Studi IImu Tanaman. Program Magister (S2). Program Pascasarjana Universitas Sriwijaya, Palembang.

Muchtadi, T. dan F. Ayustaningwarno. 2010. Teknologi proses pengolahan pangan. Institut Pertanian Bogor Press, Bogor.

Murad, H. A. and M. S. Foda. 1992. Production of yeast polygalacturonase on diary waste. Bioresour. Technol. 41: 247-250.

Murad, H. A and M. M. Salem. 2001. Utilization of uf-permeate for producing exo-polysaccharides from lactic acid bacteria. J. Agric. Mansoura Univ. 26: 2165-2173.

Murad, H. A. and H. H. Azzaz. 2010. Cellulase and dairy animal feeding. Department of Dairy Scince. National Research Center, Dokki, Cairo Egypt.

Murni, R., Suparjo, B. L. Akmal, dan Ginting. 2008. Metode pengolahan limbah untuk pakan ternak. Buku Ajar Teknologi Pemanfaatan Limbah untuk Pakan. Laboratorium Makanan Ternak Fakultas Peternakan Universitas Jambi, Jambi.

Ogimoto, K. and S. Imai. 1981. Atlas of rumen microbiology. Japan Scientific Societies Press, Tokyo.

Pasaribu, T., A. P. Sinurat, T. Purwadaria, Supriyati, dan H. Hamid. 1998. Peningkatan nilai gizi lumpur sawit melalui proses fermentasi: Pengaruh jenis kapang, suhu dan lama proses 
enzimatis. Jurnal IImu Ternak Veteriner 3: 237-242.

Putrawan, I. D. G. A. dan T. H. Soerawidjaja. 2007. Stabilisasi dedak padi melalui pemasakan ekstrusif. Jurnal Teknik Kimia Indonesia 6: 681-688.

Rahayu, W. P., S. Maamoen, Suliantari, and S. Fardiaz. 1992. Teknologi fermentasi produk perikanan. Penerbit Pusat Antar Universitas, Pangan dan Gizi, Institut Pertanian Bogor, Bogor.

SNI. 1996. Dedak padi/bahan baku pakan. SNI 01-3178-1996/rev.92. Diakses pada 24 Maret 2014.

Steel, R. G. D. and J. H. Torrie. 1993. Principles and procedures of statistics. Edisi kedua. penerjemah GM. Penerbit PT Gramedia Pustaka Utama, Jakarta.

Sutardi, T. 1977. Ikhtisar ruminologi. Badan Khusus Peternakan Sapi Perah. Direktorat Jendral Peternakan Lembang, Lembang.

Tjardes, K. E., D. D. Buskirk, M. S. Allen, R. J. Tempelman, L. D. Bourquin and $\mathrm{S}$. R. Rust. 2002. Neutral detergent fiber concentration in corn silage influences dry matter intake, diet digestibility and performance of Angus and Hostein steers. J. Anim. Sci. 80: 841-846.

Vary, P. S., R. Biendendieck, T. Fuerch, F. Meinhardt, M. Rohde, W. D. Deckwer and D. Jahn. 2007. Bacillus megaterium from simple soil bacterium to industrial protein production host. Appl. Microbial Biotechnol. 76: 957967.

Yeong, S. W. 1982. The nutritive value of palm oil byproducts for poultry. In: Animal Production and Health in the Tropics. Jainudeen, M. R. and A. R. Omar (eds). Penerbit Universiti Pertanian Malaysia, Selangor. pp. 217222.

Zamora, A. F., M. R. Calapardo, K. P. Rosario, E. S. Luis and I. F. Dalmacio. 1989. Improvement of copra meal quality for use in animal feeds. Proc. FAO/UNDP Workshop on Biotechnology in Animal Production and Health in Asia and Latin America. pp. 312-320. 